О статье коллектива авторов [Р.О. Кантария, А.В. Ватазин, А.Б. Зулькарнаев, В.А. Степанов из ГБуз Мо МоНИКИ им. М.Ф. Владимирского, Москва, Россия] ॥туберкулез легких и кишечника у реципиента почечного трансплантатаи", опубликованной в № 2.2019 журнала ॥трансплантология»

Контактная информация: Михаил Михайлович Каабак, профр., д-р мед. наук, заведующий отделением трансплантации почки ФГБНУ «РНЦХ им. акад. Б.В. Петровского», 119991, Россия, Москва, Абрикосовский пер., д. 2, e-mail: kaabak@ hotmail.com

*Кантария Р.О., Ватазин А.В., Зулькарнаев А.Б., Степанов В.А. Туберкулез легких и кишечника у реципиента почечного трансплантата. Трансплантология. 2019;11(2):141-149. https://orcid.org/10.23873/2074-0506-2019-11-2-141-149

\title{
"Pulmonary and intestinal tuberculosis in a kidney transplant recipient", about the paper by the authors R.O. Kantariva, A.V. Vatazin, A.B. Zulkarnayev, V.A. Stepanov from Moscow Regional Research and Clinical Institute n.a. M.F. Vladimirskiy, Moscow, Russia, published in Transplantologiva Journal No. 2, 2019
}

Correspondence to: Michael M. Kaabak, Prof., Dr. Med. Sci., Head of Department of Kidney Transplantation at Petrovsky National Research Centre of Surgery, 2 Abrikosovskiy Ln., Moscow 119991 Russia,

e-mail: kaabak@ hotmail.com

БЦЖ - (BCG - Bacillus Calmette-Guerin) вакцина против туберкулеза

В работе «Туберкулез легких и кишечника у реципиента почечного трансплантата» представлен пример успешного лечения инвазивного туберкулеза легких и кишечника у пациента после трансплантации почки. К сожалению, лечение туберкулеза у реципиентов органов не всегда настолько успешно. Течение туберкулеза на фоне длительной иммуносупрессивной терапии угрожает жизни пациентов, может привести к утрате функции пересаженного органа вследствие нефротоксичности лекарств, либо в результате активизации реакции отторжения спровоцированной снижением либо отменой иммуносупрессии.

Описанный клинический случай является хорошей возможностью вернуться к вопросу о предоперационной подготовке реципиентов перед трансплантацией органов. В частности, о вакцинации против туберкулеза. Тяжесть течения туберкулеза после трансплантации не идет ни в какое сравнение с возможными осложнениями от вакцинации, поэтому вакцинация БЦж у реципиентов с отрицательной реакцией Манту следует считать важным мероприятием по подготовке к трансплантации, особенно у пациентов, прежде не вакцинированных БЦж либо у пациентов с неустановленным прививочным анамнезом.

Широко применяемый сегодня Диаскинтест высоко эффективен для выявления заболевания туберкулезом, но не позволяет выявить поствакцинальный иммунитет. Для этой цели следует использовать только реакцию Манту. Отрицательная реакция Манту указывает на отсутствие у потенциального реципиента иммунитета против туберкулеза. В случае если трансплантация выполняется не по жизненным показаниям и ее можно отложить на насколько недель, разумно ввести такому реципиенту БЦЖ. 
GOMMENTABY ON A PUBLIGATION

Трудность заключается в том, что согласно инструкции к применению БЦЖ [1], вакцинация проводится только детям при отсутствии острых или обострении хронических заболеваний. Даже если ограничиться только детьми, трудно представить себе ребенка - кандидата на трансплантацию органов в настолько здоровом состоянии. Кроме того, инструкция фрактически запрещает применение вакцины у взрослых.

Следовательно, вакцинация БЦЖ у кандидатов на трансплантацию органов возможна только of label. C другой стороны, фрормирование поствакцинального иммунитета против туберкулеза значительно снизило бы заболеваемость туберкулезом.

Возрастающее число людей, живущих в России с пересаженными органами, требует пересмотреть действующие инструкции и клинические рекомендации в части дотрансплантационной вакцинации.

\section{Литература / References}

1. Вакцина туберкулезная (БЦЖ). URL: https://grls.rosminzdrav.ru/InstrImg/0001414792/ЛC-001143-260117[2017]_1.pdf [Дата обращения 22.07.2019]. Vaccinum tuberculosis (BCG). Available at: https://grls.rosminzdrav.ru/InstrImg/0001414792/JC-001143260117[2017]_1.pdf [Accessed July 22, 2019]. (In Russ.). 